\title{
Impression of Company Size, Profitability, Earning Coefficient Response (ERC) Through Timeliness
}

\author{
Ani Yulianti, Agung Budi Sulistya, Yosefa Sayekti \\ Faculty of Economic and Busines, Department of Magister Accounting, Universitas Jember \\ Email: ani.wg1707@gmail.com
}

\section{A R T I C L E IN F O}

Received:

15 January 2021

Revised:

9 March 2021

Accepted:

19 March 2021

\begin{abstract}
A B S T R A C T
This study examines how firm size and profitability can influence ERC through timeliness. This research is exploratory. The test model used is the path analysis model. The population used by this study are manufacturing companies listed on the Indonesia Stock Exchange (IDX) for the 2014-2018 period. The method used in sampling is purposive sampling method. The number of companies that met the assessment criteria was 58 companies, so that the number of observations during 2014 - 2018 was 290 observations. Data collection techniques using documentation data. The data analysis technique in this study used descriptive statistics and classical assumption tests and path analysis. Based on the results, it can be concluded that company size and profitability do not have a positive effect on timeliness, company size and profitability that are interacted with the EU has no effect on ERC, while the timeliness of submitting financial reports that are interacted with the EU has an effect on ERC. Firm size and profitability have no effect on ERC with timeliness as an intervening variable.
\end{abstract}

Keywords: Size, ROA, CAR, Timeline

Cite this as: Yulianti, A., Sulistya, A. B., Sayekti, Y. (2021). Impression of Company Size, Profitability, Earning Coefficient Response (ERC) Through Timeliness. Wiga: $\begin{array}{llll}\text { Jurnal Penelitian Ilmu Ekonomi, 11(1), } & \end{array}$ https://doi.org/10.30741/wiga.v11i1.654

\section{INTRODUCTION}

The Indonesian capital market has experienced a very fast development, as evidenced by the increasing number of issuers each year. The capital market is also an alternative source of funds, which attracts investors. This condition continues as a result of the influence of the world capital market on global economic turmoil, where the capital market helps companies develop business and invest in the long term by investors. The existence of company profit information will have a significant impact on decisions. So that the earnings information obtained can provide different market reactions to this information and attract investors. A high ERC is a reflection of a strong market reaction (Nofianti, 2014). Measuring the relationship between earnings and stock returns as an $E R C$ indicator (Kurniawati, 2014). Whereas the price of securities will immediately reflect 
new information on the market which is an explanation of the theory of efficient markets, this theory when announcing earnings about an increase or decrease in earnings must be consistent with the stock price. ERC is also interpreted as responding to the components of unexpected earnings of companies that are reported in the issuance of securities as an estimate or measurement of the level of abnormal returns of securities (Scott, 2012). While Cho, J \& Jung (1991) ERC in is defined as the impact of earnings surprises on the return of shares per dollar, measured by the coefficient of the regression of return is not normal stock and unexpected earnings. The market response occurs when the earnings announcement from the company contains information for investors to make decisions and is indicated by the price movements of the securities issued.

Research on ERC originated from the study of Ball \& Brown (1968), that the increase (decrease) in stock prices is caused by an increase (decrease) in profits. Finally, the research develops as a regression coefficient between abnormal stock returns and unexpected earnings, which is a measure of $E R C$. In other words, the response to the unexpected component of earnings announced by the firm to measure changes in abnormal returns as ERC. The quality of profits obtained by a company can affect the response of investors ( Easton \& Zmijewski, 1989). That investors are interested in earnings information with high earnings quality (Molaei et al, 2012). High quality company profits if company profits increase, (Hejazi et al 2015). The efficient market hypothesis according to Fama (1991) is that based on changes in information, stock prices adjust quickly. Therefore, ERC is defined as a result of the announcement of company earnings that enter market information, so there is an estimate of changes in stock prices (Dhaliwal, et al. 1991). Research on ERC contains several factors that can influence it, including company size, profitability, company growth, capital structure, audit quality, leverage, company age. Of the several factors considered capable of influencing $E R C$ and will be further developed by researchers, are profitability and company size. Because these two factors are considered to be able to influence $E R C$, this has the reason that a company can be said to be large if the greater the company's assets, the greater its sales and capital, and will be increasingly recognized by the public so that it will affect the quality of its earnings, as well as profits. companies because with the amount of profit that a large company gets, the investor's trust in the company will increase, so it also affects the $E R C$ level .

There are several factors that have been done by previous studies, but there are still many differences in results due to factors of research limitations and the time used for research. Research that uses the firm size factor provides differences in the understanding of investors, and large companies tend to get greater trust and response from investors, including research by Setiawati et al. (2014), Dira \& Astika (2014), Sandi (2013), in their research concluded that the effect of company size on the earnings response coefficient is very significant, in line with the study of Ginting (2017) which shows that company size has a positive relationship with the earnings response coefficient. . Meanwhile, research conducted by Dewi \& Puspaningsih (2019) , Pranandari et al. (2014), Widiatmoko \& Indarti (2018) who say that the earnings response coefficient does not have a significant effect on firm size, this is also supported by research (Ginting, 2017), Murwaningsari (2008) states that one of the negative effects on ERC is company size. . In addition, research conducted by Ratnasari et al. (2017) and (AAPK Dewi \& Putra, 2017) also argue that company size has no significant effect on $E R C$. This shows that the lower the ERC level the higher the size of the company. Larger companies are expected to be relatively stable and profitable, so that larger companies tend to attract more investors. The easier it is for the market to interpret the information in the financial statements and the more credible the more information is available about the company's activities. Therefore, the size of the company has a relationship with $E R C$.

Profitability is defined as the company's ability to generate profits to increase shareholder value. Profitability is related to the market's response to company profits and is very important to consider in knowing the extent to which the investment made by investors can provide returns in accordance with the level required by investors. Besides, profitability is a reflection of the 
company's effectiveness in influencing investors' response to earnings information in making investment decisions. Profitability is one of the factors for assessing the performance and efficiency of a company so that it is related to the profits it generates. Investor confidence is greater if the greater the profitability generated by the company, so that the quality of the resulting earnings will be better. In research conducted by Setiawati et al. (2014), Murwaningsari (2008) concluded that profitability has a positive effect on $E R C$, this research is the same as that conducted by (Hasanzade et al. 2013), while research conducted by Dewi \& Puspaningsih (2019), Setiawan (2017), Fauzan \& Purwanto (2017) concluded that earnings quality is not influenced by profitability. These results indicate that there are differences in the results of the research carried out by each study. ERC that is higher on the company's profit means that the company has high profitability than companies with low profitability. Profitability is a measure of the ability of assets owned by a company to generate income. Research conducted by Setiawati et al. (2014) argue that the comparison between profit and assets or capital that produces profit is shown in the company's profitability. A high $E R C$ value is a reflection of the strong market response to earnings information. The indication is the market assesses the reported earnings as of good quality or vice versa. So companies with high profitability have a higher ERC than companies with low profitability (Mulianti \& Ginting, 2014).

From several factors that influence $E R C$, the researcher tries to relate the effect of profitability and firm size on $E R C$ with (timelines) the timeliness of financial reporting. Where the timeliness is an attempt to measure the quality of financial reports and transparency as well as the information used by users of financial reports before losing meaning to users of financial statements in making decisions with their available capacity. Timeliness is the company's obligation to submit periodic reports. Decree of the Chairman of Bapepam and Financial Institutions Number: KEP-431 / BL / 2012 regarding the submission of annual reports of public companies or issuers, that public companies or issuers whose registration has become active and effective are required to provide annual reports to Bapepam and financial reports no later than 4 (four ) months after the end of the financial year. Then, the public company or issuer must make an annual report on the website of the public company or issuer at the same time as submitting the annual report to the Financial Services Authority (OJK) and LK. Starting 12 December 2012, Bapepam changed its name to the Financial Services Authority (OJK) as the capital market supervisory agency in Indonesia. Financial Services Authority Regulation Number 29 / POJK.04 / 2016 provides an explanation that annual financial reports and audited financial reports must be submitted to OJK with a deadline (120 days ) at the end of the fourth month after the closing date of the company's books. OJK on January 1, 2017 revoked and declared that the decision of Bapepam and LK Number KEP-431 / BL / 2012 dated August 1, 2012 is no longer valid, namely a decision containing the submission of the annual report of the issuer or public company along with its attachment to rule number XK6. So that it can provide certainty that the right time for a company to report financial statements is an obligation that must be fulfilled by the company to its users. Companies must be consistent in publishing financial statements, so that the benefits of the information in the financial statements are not lost.

The influence of the timeliness of the submission of financial reports also takes into account the factors of company size and profitability. Where an important characteristic for financial statements is the timeliness of financial reporting (Dyer \& McHugh, 1975). The results of his research with the timeliness of the submission of financial statements are shown by the size of the company whose end date the financial year is statistically significant. Meanwhile, Owusu \& Ansah (2000) , Paramita (2014), E Janrosl (2018) in their research also show that time lag in financial reporting has an effect on company size. There is a difference with research conducted by Aprianti (2017) , Jayanti (2018) concluded that timeliness is not influenced by company size but timeliness affects profitability, this is the same as research conducted by Mareta (2015) which concluded that the timeliness of financial reporting is affected. the profitability variable and the timeliness of the company's financial reporting are not influenced by company size Profitability describes the profits a company gets, thereby increasing the confidence of owners and investors of the company 
and with the timeliness of filing financial statements, the company is considered consistent in its activities. Research conducted by Astuti \& Erawati (2018), Owusu \& Ansah (2000), Aprianti (2017) concludes that the timeliness of submitting company financial statements is influenced by profitability. Evidenced by the profit generated by the company. So profit is good news for the company. Meanwhile, research conducted by Hantono (2015), Dyer \& McHugh (1975), Ramadhaniyati \& Budisusetyo (2017) concluded that profitability does not have a significant effect on timelines or timeliness. So that than companies that experience losses, companies that can make profits tend to be more timely in providing financial reporting. If the financial statements are not carried out on time by the company, a user perception will arise that the information in the financial statements contains false information. There are several studies that test the timeliness of submitting financial reports with $E R C$, such as research conducted by Fauzan \& Purwanto (2017), this research shows that timeliness does not have a relevant effect on ERC. Meanwhile, Paramita (2014) in her research concluded that there is a relevant influence between earnings response and timeliness of financial report submission. This means that the timeliness of financial reporting affects the quality of earnings which the market responds to is very credible.

The results of previous research are different, it is necessary to develop a continuous research conducted by previous researchers, because there are inconsistent results regarding company size and profitability against $E R C$. Therefore this study wants to try to include one factor, namely the timely delivery of financial reports as an intervening variable for observations that have a direct and indirect effect on company size and profitability with $E R C$. Researchers assume that the variables studied are also influenced by timeliness, because if a company provides timely financial reports, it can improve the quality of information about earnings in the company and can be responded quickly by investors and can also be used to convince investors to companies that investors will easily invest in. In this study, manufacturing companies that are on the Indonesian Stock Exchange (BEI) were selected because they are mostly compared to other types of companies so that investors are more interested in making investment places. The hypotheses proposed in this study are: Hypothesis 1 (H1) : Company size affects the timeliness of financial reporting (timeliness), Hypothesis $2(\mathrm{H} 2)$ : profitability affects the timeliness of financial reporting (timeliness), Hypothesis 3 (H3) : Firm size has an effect on ERC, Hypothesis 4 (H4) : Profitability affects ERC, Hypothesis 5 (H5) : Timeliness affects earning coefficient response $(E R C)$.

\section{METHOD}

Based on its nature, this research is exploratory because further testing of a study is needed, so the research is exploratory. The test model used is the path analysis model . The population used by this study are manufacturing companies listed on the Indonesia Stock Exchange (IDX) for the 2014-2018 period. The method used in sampling is purposive sampling method. Sampling is carried out based on the following criteria : 1) Manufacturing companies listed on the IDX that publish financial reports for 2014-2018. 2) Companies that have never been delisted from the IDX during the 2014-2018 period. 3) Manufacturing companies that have positive company profits during the 2014-2018 period. 4) Manufacturing companies which during the study period used the rupiah currency. 5) Manufacturing companies which during the research have complete data. The number of companies that met the assessment criteria was 58 companies, so the number of observations during 2014 - 2018 was 290 observations. The technique of collecting da ta use documentation data by collecting the company's annual report in 2014-2018 were obtained from the website Indonesia Stock Exchange and the website of each company into the sample.

Company size is the size of a company as seen from the total assets owned by the company (Rofika, 2013). In this study, company size is proxied by using Ln to total assets using the natural $\log$. Size $=\log _{\mathrm{n}} \mathrm{x}$ total assets. Profitability in this study uses the return on asset ratio 
(ROA) which is used to measure the company's ability to generate profits. Which ROA can show the efficiency of the company in managing all of its assets to earn income, according to Hanafi \& Halim (2018: 157), which states that: " Return On Assets is a measure of the company's ability to generate profits by using the total assets (wealth) owned by the company after adjusting the costs to finance these assets." So that the formula used according to Hanafi \& Halim (2018: 158) to calculate the profitability of the company in this study is as follows: ROA = net profit/ total assets.

Timeliness is the availability of information to decision makers before the information is losing its capacity to influence decisions. If the information is not available when it is needed to make decisions, then the information is no longer relevant and has no benefit in decision making (Hanafi \& Halim, 2018: 36) . This variable is measured based on the date of submission of the audited annual financial statements. This variable is measured using the timeframe for the announcement of audited (audited) annual financial statements to the public, namely the number of days it takes to announce the audited annual financial statements to the public, from the closing date of the company's financial year to the date of submission to Bapepam (Paramita , 2014). In accordance with the regulations of the Financial Services Authority Number: 29 / POJK.04 / 2016 concerning the annual report of the issuer or public company, the submission of the audited annual financial report is said to be timely if it is submitted before or no later than the end of the third month after the date of the company's annual financial report the public. Earning Response Coefficient $(E R C)$ is a form of measuring the information content in earnings. Which earnings information is whether it reflects the actual condition of a company. So that this information can be used in making a decision and can also increase the usefulness of decisions in financial reporting . ERC is the coefficient obtained from the regression between the proxies of share prices and accounting earnings. The proxy for share price used is Cammuative Abnormal Return (CAR), while the proxy for accounting profit is Unexpected Earnings $(U E)$.

The dependent variable in this study is cumulative abnormal return (CAR) which is calculated during the observation period, which is approximately 5 days from the date of publication of the financial statements, because on that observation date, stock prices tend to fluctuate a few days before and after the publication of financial reports. ERC calculations are carried out according to Awuy et al. (2016) with several stages: Calculating the CAR (Cammulative Abnormal Return ) $C A R_{i(-5+5)}=\sum_{t=-5}^{t=+5} A R_{i t}, C A R_{i(-5+5)}$ : cumulative abnormal return of company i during the observation period of approximately 5 days from the date of publication of the financial statements. ( 5 days before the date of publication and 5 days after the date of publication of the financial statements), ${ }^{A R_{i t}}$ : abnormal return of company $i$ on day $t$.

Stock returns and company market returns are calculated using an observation time of 11 days, because $C A R$ when accounting earnings are published can be calculated in the event window for 11 days ( 5 days before the event, 1 day of the event, and 5 days after the event) because stock prices tend to be fluctuation in the days before and after the publication of earnings.

In this study, abnormal returns are calculated using a market-appropriate model, Jogiyanto (2014). Abnormal returns are obtained from: ARit $=$ Rit - Rmt, ARit $=$ Abnormal return of firm $i$ in period $\mathrm{t}$, Rit $=$ Company return in period $\mathrm{t}, \mathrm{Rmt}=$ Market return in period $\mathrm{t}$. To obtain the abnormal return data, you must first look for daily stock returns and daily market returns . a) Calculate the daily stock return with the formula: Rit $=($ Pit - Pit-1) Pit-1, Rit $=$ Company i stock return on day $\mathrm{t}, \mathrm{Pit}=$ closing price of share $\mathrm{i}$ on day $\mathrm{t}$, Pit- $1=$ closing price of share $\mathrm{i}$ on day $\mathrm{t}-1 . \mathrm{b}$ ) Calculates daily market returns. Rmt $=($ IHSGt - IHSGt-1) $\mathrm{IHSGt}-1, \mathrm{Rmt}=$ Daily market return IHSGt $=$ composite stock price index on day $\mathrm{t}$, IHSGt- $1=$ composite stock price index on day $\mathrm{t}-1$

Umexpected Earnings (UE) calculated by means of the random walk model. Unexpected Earninga $(U E)$ can be interpreted as the difference between realized accounting profit and market expected profit. So the EU variable is calculated from the profit per share for the current year minus the 
profit per share in the previous year divided by the price per share in the previous year. Unexpected Earnings (UE) is measured according to Paramita's (2014) research: UEit = (EPSit-EPSit-1)

Pit-1 , UEit = Unexpected Earnings for company I in period t, EPSit = Earnings per share of company $\mathrm{I}$ in period $\mathrm{t}$, Pit-1 = The company's stock price in period $\mathrm{t}-1$

Furthermore, to see the effect of company size, profitability, timeliness on ERC, the variables of company size, profitability and timeliness will be interacted with in a regression equation with an interaction model.

The data analysis technique in this study used descriptive statistics and classical assumption tests and path analysis. The data must meet the classic assumption tests in the form of normality, multicolonierity, autocorrelation and heterocedasticity tests. The data that has passed the classical assumption test are then carried out by using path analysis. The path coefficients calculated by making two structural equation, namely: (1) Formulate hypotheses and structural model-1 equations. Model 1 is timelines $=\alpha+b 1$ Size $+b 2$ Profit $+\epsilon_{1}$. (2) Formulate hypotheses and structural model-2 equations. Model 2 is CAR $=\alpha+\mathrm{b} 1 \mathrm{UE}+\mathrm{b} 2 \mathrm{Size}+\mathrm{b} 3$ Profit $+\mathrm{b} 4 \mathrm{Timelines}+$ $\mathrm{b} 5(\mathrm{UE} *$ Size $)+\mathrm{b} 6$ (UE * Profit) $+\mathrm{b} 7$ (UE * Timelines) + 2 2. CAR: Cummulative Abnormal Return, UE : Unexpexted Earnings, Size: Company size, Profit: Profitability, Timelines: Punctuality of time, UE * Size: The interaction of the UE and Size variables, UE * Profit: Interaction of the EU variables and Profit, UE * Timelines: Interactions of UE variables and Timelines

The effect of mediation indicated by the multiplication of the coefficient can be determined to be significant by being tested using the Sobel test (Ghozali, 2013).

\section{RESULTS AND DISCUSSION}

Tabel 1. Descriptive Statistic

\begin{tabular}{lccccc}
\hline & Minimum & Maximum & Mean & $\begin{array}{c}\text { Standard } \\
\text { Deviation }\end{array}$ & N \\
\hline Size & 11.4800 & 19.6200 & 14.8578 & 1.6614 & 290 \\
Profitabilitas & 0.0200 & 52.6700 & 8.3815 & 8.6489 & 290 \\
Timelines & -0.0100 & 17.000 & 0.6525 & 1.3992 & 290 \\
UE & -4.1224 & 28.7745 & 0.0742 & 1.7665 & 290 \\
CAR & -0.9450 & 2.2751 & 0.0627 & 0.3144 & 290 \\
UE*Size & -55.5287 & 342.7043 & 0.8202 & 21.3485 & 290 \\
UE*Profitabilitas & -74.1782 & 153.0803 & -0.0348 & 11.4264 & 290 \\
UE*Timelines & -2.9681 & 15.5382 & 0.0208 & 0.9477 & 290 \\
Valid N (Listwise) & & & & & \\
\hline SOurce: SPSS data & & & & &
\end{tabular}

Source: SPSS data $(2020) * n=58 \times 5$ years $=290$

The size of the company is measured using the company's total assets. It shows that the lowest value of the company size is 11.48 , the highest value is 19.62 and the average value is 14.8578 , with a standard deviation of 1.6614 where the standard deviation value is smaller than the average value . Profitability is measured by the ratio of return on assets (ROA), which is the ratio between net income and total assets of the company. It shows that the lowest value of profitability is 0.02 , the highest value is 52.67 and the average value is 8.3815 , with a standard deviation of 8.6489 where the standard deviation value is greater than the average value, this means that the data deviation that occurs is high because the data distribution fluctuates. Timelines which are measured by looking at the date of financial reporting shows that the lowest value of timeliness is 0.0100 , the highest value is 17.00 and the average value is 0.6509 with a standard deviation of 
1.3996, where the standard deviation value is greater than the value. on average, this means that the data deviation that occurs is high because the data distribution fluctuates. Unexpected Earnings $(U E)$ shows that the lowest value from the UE is -4.1224 , the highest value is 28.7745 , and the average value is 0.0742 and the standard deviation value is 1.7665 where the standard deviation value is greater than the average value, this means that the data deviation which happens is high because the data distribution fluctuates i. Cumulative abnormal return (CAR) shows that the lowest value of CAR is -0.9450 , the highest value is 2.2751 , and the average value is 0.0627 and the standard deviation value is 0.3144 where the standard deviation value is greater than the average value, this means that the data deviation what happens is high because the spread of the data fluctuates. EE multiplied by Size, UE multiplied by Profit and UE multiplied by Timelines shows the lowest values are $-55.5287,-74.1782,-2.9681$, respectively, the highest value is 342.7043 respectively. $153.0803,15.5382$ while the average value is $0.8203,-0.0348,0.0208$ and the deviation value is $21.3485,11.4264,0.9477$ where if the standard deviation value is greater than the average value, this means that the data distribution fluctuates.

After knowing the values in the descriptive statistical test, then the classical assumption test is carried out to determine the correlation or relationship between variables. After doing the outlier test, the Si significant value was obtained at 0.200 , so it can be concluded that the residual data is normally distributed. U kuran and profitability has a value of tolerance 0.913 greater than the value of $0,10(0.913>0.1)$ and has a value of 1.096 VIF smaller than $10(1.096<10)$, it can be concluded that the data is free from multicoloniarity. Whereas the variable company size, profitability, EU, Timeline shows tolerant values of $0.849,0.861,0.005,0.992$ and has a VIf of $1.178,1.162,217.185,1.008$. While the interaction variable UE * Size, UE * Profitability and the interaction variable $\mathrm{UE} *$ Timelines have a tolerance value of $0.005,0.005,0,506$ and 0.143 and have VIF values of $217,185,196,067,1,975,6,995$ where the tolerant value is smaller than 0.10 and the VIF is more greater than 10, this value is in the UE variable and the interaction variable $\mathrm{UE} *$ Size which is the main variable to be tested, so these two variables cannot be removed from the model. However, this must be considered in the interpretation of the results of further regression model testing.

The results of the autocorrelation test using the Durbin Watson test model 1 obtained a Durbin Watson value of 1.665. The autocorrelation test criteria for Durbin Watson, the value of 1.665, is between 1.55 and 2.46 which has the conclusion that the model does not experience autocorrelation or residual symptoms that have no correlation with other observations arranged according to time series. In model II the value is 1.935 . The autocorrelation test criteria for Durbin Watson, the value of 1.665 , is between 1.55 and 2.46 which has the conclusion that the model does not experience autocorrelation or residual symptoms that have no correlation with other observations that are arranged according to time series. The results of the Heteroscedasticity test show that the regression model 1 with the independent variable firm size and profitability on the residual absolute dependent variable does not show any symptoms of heteroscedasticity with a significance value of 0.296 and 0.999 respectively greater than 0.05 , it can be concluded that regression model 1 does not contain heteroscedasticity. While the regression model 2 with the variable firm size, profit, EU independent, the interaction variable UE * Size, UE * Profitability, UE * Timelines on the residual absolute dependent variable did not show any symptom of heteroscedasticity with a significance value of $0.747,0.619,0.905$ and 0.274 respectively. greater than 0.05 , it can be concluded that regression model 2 does not contain any heteroscedasticity.

In this study, path analysis is used to determine the amount of contribution indicated by the path coefficient of the causal relationship between the variables of company size, profitability and timeliness as well as the causal relationship between company size, profitability and timeliness and CAR . Path analysis is also used to test the cause and effect that occurs when the independent variable affects the dependent variable directly or indirectly. After analyzing the data, and then made tracks equation model with two kinds of models, namely: Timeliness $=0.339+0.012$ Size +0.004 Profit $+e 1$, 


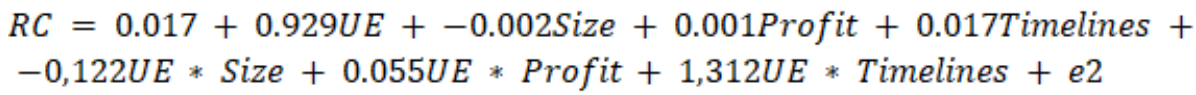

The results of the path analysis indicate that company size can have a direct effect on timeliness, the magnitude of the direct effect is 0.012. Profitability can have a direct effect on timeliness, the magnitude of the direct effect is 0.004. Company size can have a direct effect on ERC, the magnitude of the direct effect is $-0,122$. Profitability can have a direct effect on ERC, the magnitude of the direct effect is 0.055. Meanwhile, timeliness can have a direct effect on ERC, the magnitude of the direct effect is 1.312 . The indirect effect can be determined by calculating the multiplication of the indirect coefficient, namely: The indirect effect of company size on ERC through timeliness $1 \times \boldsymbol{p} 3=0.012 \times 1.312=0.0157$ Or the total effect of company size to ERC = $0.122+0,0157=-0.1063$. Indirect effect of profitability on ERC through Punctuality $\boldsymbol{p} 2 \times \boldsymbol{p} 3=$ $0.004 \times 1.312=0.0068$ Or the total effect of profitability on $\mathrm{ERC}=0.055+0.0068=0.061$.

Table 2. T Test Results

\begin{tabular}{lccc}
\hline \multicolumn{1}{c}{ Model } & $\begin{array}{c}\text { Unstandardized } \\
\text { Coefficients } \\
\text { B }\end{array}$ & $\boldsymbol{t}$ & Sig. \\
\hline Model 1 & 0,339 & 1,442 & 0,151 \\
(constant) & 0,012 & 0,765 & 0,445 \\
Size & 0,004 & 0,591 & 0,555 \\
Profitabilitas & 0,017 & & 0,610 \\
Model 2 & 0,929 & 0,511 & 0,519 \\
(constant) & $-0,002$ & 0,647 & 0,419 \\
UE & 0,001 & $-0,811$ & 0,241 \\
Size & 0,017 & 1,178 & 0,175 \\
Profitabilitas & $-0,122$ & 1,362 & 0,189 \\
Timelines & 0,055 & $-1,320$ & 0,124 \\
UE*Size & 1,312 & 1,546 & 0,002 \\
UE*Profitabilitas & & 3,164 & \\
UE*Timelines & & & \\
\hline Sour SPSS data & & & \\
\hline
\end{tabular}

Source: SPSS data (2020)

The effect of mediation shown by the multiplication of the coefficients can be determined by the significance of the test using the Sobel Test (Ghozali, 2013) as follows:

1. Compute the standard error of the indirect effect coefficient

a. Indirect effect of firm size on ERC through timeliness (Sp1p3)

$$
\begin{aligned}
& \text { Sp1p3 }=\sqrt{\text { p32 Sp12 }+ \text { p12 Sp32 }+ \text { Sp12 Sp32 }} \\
& \text { Sp1p3 } \sqrt{(1,312) 2(0,016) 2+(0,012) 2(0,415) 2+(0,016) 2(0,415) 2} \\
& \text { Sp1p3 }= \sqrt{(1,721344)(0,000256)+(0,000144)(0,172225)+(0,000256)(0,172225)} \\
& \text { Sp1p3 }=\sqrt{(0,00044066)+(0,0000248)+(0,0000441)} \\
& \text { Sp1p3 }
\end{aligned}
$$

b. Indirect effect of profitability on ERC through Punctuality (Sp2p3)

$$
\begin{aligned}
\text { Sp2p3 } & =\sqrt{\text { p32 Sp22 }+ \text { p22 Sp32+ Sp22 Sp32 }} \\
\text { Sp2p3 } & =\sqrt{(1,312) 2(0,006) 2+(0,004) 2(0,415) 2+(0,006) 2(0,415) 2} \\
\text { Sp2p3 } & =\sqrt{(1,721344)(0,000036)+(0,000016)(0,172225)+(0,000036)(0,172225)} \\
\text { Sp2p3 } & =\sqrt{(0,00006197)+(0,0000027556)+(0,0000062)}
\end{aligned}
$$


Calculating the $\mathrm{t}$ statistical value or $\mathrm{t}$ counting the effect of mediation is as follows: Model 1 $t=\frac{p 1 p 3}{S p 1 p 3}=\frac{(0,012)(1,312)}{0,1316184}=\frac{0,015744}{0,02257}=0,697563$.

First, the $\mathrm{t}$ table value is determined where the $\mathrm{t}$ table value with $\alpha=5 \%$, df $(n-2)$ is obtained t table $(\alpha / 2 ; 139-2)=(0.025 ; 139)$ is obtained, namely \pm 1.97718 . Therefore the value of $t$ arithmetic 0.697563 smaller than $t$ table 1.97718 with a significance level of 0.05 , it can be concluded that timeliness is not proven to be pemediasi between the size of the company ERC.

Model 2. $\mathrm{t}=\frac{p 2 p 3}{S p 2 p 3}=\frac{(0,004)(1,1312)}{0,0084217}=\frac{0,005248}{0,0084217}=0,6231521$.

First, the $t$ table value is determined where the $t$ table value with $\alpha=5 \%$, df $(\mathrm{n}-2)$ then we get the $t$ table $(\alpha / 2 ; 139-3)=$ $(0.025 ; 139)$ which is \pm 1.97718 . Therefore the value of $\mathrm{t}$ arithmetic 0.6231521 is smaller than t table 1.97718 with a significance level of 0.05 , it can be concluded that timeliness is not proven to be pemediasi between the profitability of the $E R C$.

Based on the results of hypothesis testing, it shows that company size has no effect on the timeliness of financial reporting. The results show that the path coefficient value of 0.445 has a significance greater than $\mathrm{a}=5 \%(0.445>0.05)$. A significance value greater than 0.05 indicates no effect. This means that there is no influence between company size on the timeliness of financial report submission. That the size of the company cannot determine the level of confidence of investors who will invest in the company by looking at the consistency of the company in submitting its financial reports on time. The results of this study do not support the theory that has been applied, that the signal theory explains how companies should be able to provide signals to users of financial statements, and can also provide an overview and encouragement for companies to provide financial information to investors. The results of this study do not support research conducted by Owusu \& Ansah (2000), Paramita (2014), but this research supports research conducted by Aprianti (2017) and Jayanti (2018) which state that company size does not have a significant effect on accuracy. time to submit financial reports.

Profitabilitas no effect on punctuality. The results show that the path coefficient value of 0.555 has a significance greater than $a=5 \%(0.555>0,05)$. A significance value greater than 0.05 indicates no effect. This means that profitability cannot determine the level of confidence of investors in the company because even though the level of profit generated is large, it is not certain that the delivery of financial statements is timely so that the information generated cannot influence investors in investing their capital. The results of this study do not support the applied theory that the signal theory explains the information contained in an announcement in the financial statements that can later provide a signal in decision making by investors. Where should the information on profitability be good news for companies that must be conveyed to the public, so that it will increase the timeliness of submitting financial statements. Therefore, companies with high profitability is not a guarantee would be timely in reporting financial statements. This study supports the research of Hantono (2015), Ramadhaniyati \& Budisusetyo (2017). However, this study does not support research conducted by Aprianti (2017), Astuti \& Erawati (2018) that profitability has a positive influence on timeliness.

Company size does not affect the ERC. The results show that the path coefficient value of the company size interacted with the EU is 0.189 , which is a significance greater than a $=5 \%$ (0.189>0.05). A significance value greater than 0.05 indicates no effect. The size of the company cannot provide a response to investors, the result of this study does not support the signal theory that looking at the size of the company will not be able to provide a good signal for the company which will provide a quick response to investors in assessing the company so that investors will be interested to invest. So even though the company is large, it is not certain that it can give a good response to investors because most manufacturing companies are large companies, 
so investors prefer to see the company's market conditions in general rather than looking at its assets, and also because of other factors such as good governance. play a more important role in generating investor responses than profits. This study supports the research of Dewi \& Puspaningsih (2019), Pranandari et al. (2014), and Widiatmoko \& Indarti (2018) . However, this study is not supported by research by Setiawati et al. (2014), Dira \& Astika (2014), Sandi (2013) stated that company size has an effect on $E R C$.

Profitability has no effect on the $E R C$, results showed coefficient of profitability diinteraksikan path to the EU amounted to 0.124 have more significance than a $=5 \%(0.124>0.05)$. A significance value greater than 0.05 indicates no effect $\mathrm{H}$ al This means that the profitability of a company's ability to generate profits. Profit information generated by a company can not provide a response to investors, even though the generated profits will not be quickly responded to by investors so that they will not get the confidence of investors to invest their capital. This result is not in accordance with the market efficiency theory that high-quality earnings information at the time of earnings announcements will get a positive response from investors so that an increase in profit will be followed by an increase in stock prices, this shows that with high profitability it will show good company performance, investor response will be increases along with the increase in company performance. In this case, profitability cannot trigger a market response to earnings information, which indicates that profitability cannot provide a good contribution to investors in assessing market conditions. Meanwhile, the signal theory also explains that a high level of profitability will have a high $E R C$ value. With high profitability, it will provide a good signal for investors in making decisions about the company. This research supports research conducted by Dewi \& Puspaningsih (2019), Setiawan (2017) and Fauzan \& Purwanto (2017). However, this study does not support the research of Setiawati et al. (2014), Hasanzade et al. (2013) stated that profitability has a positive effect on $E R C$.

Accuracy of positive effect on the $E R C$. The results show that the path coefficient value of the punctuality of interaction with UE is 0.002 , which is less than a $-5 \%(0.002<0,05)$. A significance value less than 0.05 indicates a significant effect. This means that the timeliness of the financial statements can have a positive impact on market response, with the timeliness of the delivery of financial information will have an effect on the quality of earnings generated by the company. This will give investors confidence that companies that report their financial reports in a timely manner will be responded to more quickly by investors than companies that do not report in a timely manner.

The results of this study support the applied theory that with signal theory it is said that if a company's financial statements are submitted in a timely manner, investors will respond more quickly because the timeliness of delivering financial reports has an influence on the credibility or earnings quality. The company's disciplinary activities in delivering financial reports that are carried out on time will give a signal to investors that the company is in good health and reduces noise in its reports so that it will increase investors' response to profits which will be responded to by investors in making a decision. In this study, the timeliness of the submission of financial reports will have a big influence on investors because on time investors will have more confidence that the company is in good condition, and also the information conveyed in its financial statements is relevant so that it will benefit users of the information. . The results of this study support research conducted by Paramita (2014), Murwaningsari (2008) that punctuality has an effect on $E R C$ while firm size has an effect on timeliness. And this study does not support the research conducted by Fauzan \& Purwanto (2017) that punctuality has no effect on ERC.

Company size does not influence on the $E R C$ through punctuality have indirect influence. The results show that the path coefficient value of 0.697 has a significance greater than a $=5 \%$ $(0.697>0.05)$, a significance value greater than 0.05 , it can be concluded that timeliness is not proven to be a mediator between firm size and $E R C$. This means that the size of the company cannot determine the level of investor confidence in investing in the company through timeliness 
in the delivery of financial statements. But here investors will react by looking at the size of the company alone regardless of whether the company is on time or not in submitting financial statements. This research does not support the signal theory that if you look at the size of the company is large, the larger the company size the more resources, the more many accounting staff and sophisticated information systems so that the company will be faster in completion and will be more timely in submitting financial reports so that the information will provide positive information from investors. So the researcher argues that the size of a company size and its timely delivery cannot determine the level of confidence in investors. So this research supports the research conducted by Murwaningsari (2008) and does not support the research conducted by (Paramita, 2014).

Profitability has no effect on the ERC through punctuality have indirect influence. The results showed that the value of the path coefficient 0.623 has a greater significance than $a=5 \%(0.623>$ 0.05 ) significance values greater than 0.05 , it can be concluded that timeliness is not proven to be pemediasi between the profitability of the ERC This meant that profitability is an indicator of the success of a company to be able to generate profits, which earnings information cannot be responded to well by investors even though the company is timely in its delivery. The earnings information announced by the company is a signal aimed at the market with the aim of prompt response by investors for the announced earnings announcement, however the earnings information cannot be received well by investors. The signal theory explains that high profitability will have a high $E R C$ value. High profitability will provide a good signal for investors in making a decision on the company. Researchers assume that punctuality is not the only factor that the company takes into account that the earnings announcements that are generated will get investors' response, but with profitability it will produce high quality earnings which will get a response from investors.

\section{CONCLUSION}

Based on the results of hypothesis testing and refers to the formulation and the purpose of this study, it can be deduced u kuran perus Ahaan no effect on the timely submission of financial statements, it is said that by looking at the size of the company can not determine the level of investor confidence in the company so that investors not interested in investing. Profitability does not affect the timeliness of the submission of financial reports, with the presence of high profitability information, it cannot determine the level of investor confidence in the company and not necessarily in the delivery of financial reports on time. The size of the company does not b erpengaruh t erhadap ERC. In this case, this means that with the size of the company it can not give a different response to the company, a large company is not necessarily able to generate good profits so that in its operations it still requires funds from outside parties . Profitability is not b erpengaruh to the $E R C$. In this case the profitability does not reflect the effectiveness of the company in influencing investors on their information nical profit although earnings at yield increases are not going to be faster in the response by investors so is not going to get the confidence of investors to invest.

The timeliness of the submission of financial reports has an effect on the ERC that the timeliness of the financial statements can have a positive impact on market response, the timeliness of the delivery of financial information will affect the quality of earnings generated by the company so that it will gain the trust of investors in the company.. Firm size has no effect on ERC with timeliness as an intervening variable. With the timeliness of financial reporting can not be guaranteed that a large-sized enterprise ak 's getting investor response tet fire here investors will react by looking at the size of the company without regard to the company on time or not in the delivery of financial statements. Profitability has no effect on ERC with timeliness as an intervening variable. Profitability which is an indicator of the success of a company to be able 
to generate profits. Investors could not respond well to the earnings information even though the company was delivered on time.

This research is a development from previous research to analyze indirect effects, so that researchers have difficulty determining the theories used to connect between research variables. The high multicollinearity found in the EU variable and the variable that is proxied by the total asset (UE* Size) of these variables cannot be avoided because it is the main variable to be tested. It is hoped that further researchers will be able to explore more deeply the supporting theories used, and it is expected to find ways of mechanisms related to this multicollinearity so that the resulting coefficient estimates are not biased.

\section{REFERENCE}

Anggraeni Diah Kurniawati. (2014). Pengaruh Karakteristik Perusahaan Terhadap Earnings Response Coefficient. Akuntansi Bisnis, XIII(25), 1-24.

Aprianti, I. (2017). Pengaruh Ukuran Perusahaan , Profitability , Dan Debt Equity Ratio Terhadap Ketepatan Waktu Pelaporan Keuanga Industri Food And Beverages Dan Sektor Industri Tekstile Yang Terdaftar Di Bursa Efek Indonesia ). Ekonomi,Bisnis \& Entrepeneurship, 11(1), 37-46.

Astuti, W., \& Erawati, T. (2018). Pengaruh Profitabilitas, Umur Perusahaan Dan Ukuran Perusahaan Terhadap Ketepatan Waktu Penyampaian Laporan Keuangan Perusahaan (Studi pada perusahaan manufaktur yang Terdaftar di Bursa Efek Indonesia Tahun 2012-2016). Kajian Bisnis, 26(2), 144-157.

Awuy, V. P. et al. (2016). Pengaruh Pengungkapan Corporate Social Responsibility ( CSR ) Terhadap Earnings Response Coefficient ( ERC ) ( Suatu Studi Empiris Pada Perusahaan Pertambangan yang Terdaftar di Bursa Efek Indonesia Pada Tahun 2010-2013 ). Jurnal Akuntansi Dan Keuangan, 18(1), 15-26. https://doi.org/10.9744/jak.18.1.15-26

Bagus Rahmad Setiawan. (2017). Pengaruh Ukuran Perusahaan, Profitabilitas, Likuiditas Danleverageterhadap Kualitas Laba Pada Perusahaan Manufaktur Industri Barang Konsumsi Yang Terdaftar Di BEI. XI(77), 36-46.

Ball, R., \& Brown, P. (1968). An Empirical Evaluation of Accounting Income Numbers. Of Accounting Research, 6(2), 159-178.

Cho, J, Y., \& Jung, K. (1991). Earning response coefficients: A synthesis of theory10 and empirical evidence. Accounting Literature, 10, 85-116.

Dewi, A. A. P. K., \& Putra, I. M. P. D. (2017). Pengaruh Leverage Dan Ukuran Perusahaan Pada Earnings Response Coefficient. 19(1), 367-391.

Dewi, S. P., \& Puspaningsih, A. (2019). Determinants analysis of earnings response coefficient: Empirical study in Indonesia. Jurnal Akuntansi \& Auditing Indonesia, 23(2), 90-98. https://doi.org/10.20885/jaai.vol23.iss2.art3

Dhaliwal, D. A. N. S., J.LEE, K., \& Neil L,FargherUniver, J. L. E. E. (1991). The association between unexpected earnings and abnormal security returns in the presence of financial leverage *. X(1), 20-41.

Dira, K. P., \& Astika, I. B. P. (2014). Pengaruh struktur modal, likuiditas, pertumbuhan laba, dan ukuran perusahaan pada kualitas laba. Akuntansi, 1, 64-78.

Dyer, J., \& McHugh, A. (1975). Timeliness Of Australian Annual-Report. Accounting Research, 13(2), 204-219.

E Janrosl, V. S. (2018). Analisis Pengaruh Leverage, Ukuran Perusahaan Dan Profitabilitas Terhadap Ketepatan Waktu Pelaporan Keuangan Pada Perusahaan Perbankan. Jurnal Benefita, 3(2), 196. https://doi.org/10.22216/jbe.v3i2.3464

Easton, P. D., \& Zmijewski, M. E. (1989). Cross-Sectional Variation In The Stock Market Response To Accounting Earnings Announcements. Accounting and Economics 11, 11, 117-141.

Fama, E. F. (1991). Efficient Capital Markets : II. Of Finance, XLVI(5), 1575-1617. 
Fauzan, M., \& Purwanto, A. (2017). Pengaruh Pengungkapan Csr, Timeliness, Profitabilitas, Pertumbuhan Perusahaan Dan Resiko Sistematik Terhadap Earning Response Coefficient (Erc) (Studi Empiris Pada Perusahaan Manufaktur, Properti dan Pertambangan yang Terlisting di Bursa Efek Indonesia (B. Of Accounting, 6(1), 1-15.

Ghozali, I. (2013). Aplikasi Analisis Multivariate Dengan Program IBM SPSS 21 (VII). Universitas Diponegoro.

Ginting, S. (2017). Pengaruh Profitabilitas, Likuiditas Dan Ukuran Perusahaan Terhadap Kualitas Laba Pada Perusahaan Manufaktur Yang Terdaftar Di Bursa Efe Indonesia. 7, 227-236.

Hanafi, M. M., \& Halim, A. (2018). Analisis Laporan Keuangan (Kelima ,Ce). UPP STIM YKPN.

Hantono. (2015). Pengaruh Likuiditas, Opini Audit, Ukuran Perusahaan Dan Profitabilitas Terhadap Ketepatan Waktu Pada Perusahaan Manufaktur Yang Terdaftar Di Bursa Efek Indonesia Periode 2011 -2013. Ekonomi Mikroskil, 5(2), 101-109.

Hasanzade, M., Darabi, R., \& Mahfoozi, G. (2013). Factors Affecting the Earnings Response Coefficient: An Empirical study for Iran. 2(3), 2551-2560.

Hejazi, R., Ansari, Z., Sarikhani, M., \& Ebrahimi, F. (2015). The Impact of Earnings Quality and Income Smoothing on the Performance of Companies Listed in Tehran Stock Exchange. Of Business and Social Science, 2(17), 193-197.

Jayanti, F. D. (2018). Pengaruh ukuran perusahaan, kualitas audit dan profitabilitas terhadap ketepatan penyampaian laporan keuangan. 14(1), 26-33.

Jogiyanto, H. (2014). Teori Portofolio Dan Analisis Investasi (BPFE (ed.); kesembilan).

Mareta, S. (2015). Analisis Faktor-Faktor Yang Memengaruhi Timeliness Publikasi Laporan Keuangan Periode 2009-2010 ( Studi Empiris Pada Bursa Efek Indonesia ). Akuntansi, XIX(01), 93-108.

Molaei, I., Molaei, D., Yari, R., \& Aghabaki, M. (2012). The Investigation of Effecting factors on Earnings Quality. 2(3), 3077-3080.

Mulianti, D., \& Ginting, J. (2014). Analisis Pengaruh Ukuran Perusahaan, Profitabilitas, Timeliness, Dan Struktur Modal Terhadap Earnings Response Coefficient Pada Perusahaan Manufaktur Yang Terdaftar Di Bursa Efek Indonesia Periode 2012-2014. 05(01), 1-24.

Murwaningsari, E. (2008). Pengujian Simultan : Beberapa Faktor Yang Mempengaruhi Earnings Response Coefficient (ERC). Simposium Nasional Akuntansi (SNA) Ke XI.

Nofianti, N. (2014). Pengaruh Struktur Modal, Ukuran Perusahaan, Dan Kebijakan Dividen Terhadap Koefisien Respon Laba. Etikonomi, 13(2), 118-147.

Owusu, S., \& Ansah. (2000). Timeliness of corporate financial reporting in emerging Capital Markets: empirical evidence from the Zimbabwe StockOwu. 30(1), 241-254. https://doi.org/10.1080/00014788.2000.9728939

Paramita, R. W. D. (2014). Pengaruh Ketepatwaktuan Penyampaian Laporan Keuangan Terhadap Respon Laba Akuntansi. WIGA, 4(2), 39-44.

Paramita, R. W. D. (2014). Timeliness Sebagai Variabel Intervening Untuk Pengaruh Ukuran Perusahaan Terhadap Respon Laba. 4(1), 34-42.

Pranandari, F., Fanani, Z., Prasetyo, K., \& Mardijuwono, A. W. (2014). Meta-Analysis : a Decade Study about the Determinants of Earnings Response Coefficient ( ERC ) in Indonesia. Of Accounting Research, 17(1), 57-91.

Ramadhaniyati, A., \& Budisusetyo, S. (2017). Faktor-Faktor Yang Mempengaruhi Ketepatan Waktu (Timeliness) Penyampaian Laporan Keuangan.

Ratnasari, D., Sukarmanto, E., \& Sofianty, D. (2017). Pengaruh Persistensi Laba, Ukuran Perusahaan dan Default Risk terhadap Earnings Response Coefficient (pada Perusahaan Perbankan yang Terdaftar di Bursa Efek Indonesia) Earnings. Proseding Akuntansi, 3(2), 117-124.

Rofika. (2013). Pengaruh Risiko Perusahaan Dan ukuran Perusahaan Terhadap Earning Response Coefficient. 5(2), 93-100.

Sandi, K. U. (2013). Faktor-faktor yang mempengaruhi earnings response coefficient. Accounting Analysis, 2(3), 337-344. 
Scott, W. R. (2012). Financial accounting theory (6th ed.). Toronto : Pearson Prentice Hall, c2012. Setiawati, E., Nursiam, \& Apriliana, F. (2014). Analisis Pengaruh Ukuran, Pertumbuhan Dan Profitabilitas Perusahaan Terhadap Koefisien Respon Laba (Studi Empiris pada Perusahaan Manufaktur yang terdaftar di Bursa Efek Indonesia (BEI) tahun 2009-2011). Research Methods and Organizational Studies, Sancall, 175-188.

Widiatmoko, J., \& Indarti, M. G. K. (2018). The Determinans Of Earnings Response Coefficient : An Empirical Study For The Real Estate And Property Companies Listed On The Indonesia Stock Exchange. Accounting Analysis, 7(2), 135-143. https://doi.org/10.15294/aaj.v7i2.27321 